\title{
Enhancing grade 5 and 6 students' outputs in MAPEH through the Google classroom
}

\author{
Mejorando los resultados de los estudiantes de grado 5 y 6 en MAPEH a través del aula de Google
}

Aprimorando os resultados dos alunos do $5^{\circ}$ e $6^{\circ}$ ano no MAPEH por meio da sala de aula do Google

\section{Jeremiah Paul G. Manuel}

jpgmanuel1984@gmail.com

Fourth Estate Elementary School BF Homes, Parañaque City, Philippines https://orcid.org/0000-0001-6597-1295

\begin{abstract}
This action research was conducted to determine if there is an improvement in the outputs submitted by Grade 5 and 6 pupils who were given modules to accomplish. Respondents of the study were the teachers from the levels above who collected module submissions during the school year 2020-2021. A descriptive design was utilized by the researcher to see if there was a significant change in the feedback of the teachers who received the modules both before and after the implementation of the intervention. The gathered data were analyzed and statistically treated using descriptive statistics. There were factors identified that contributed to the low levels of submissions. The pandemic and the quarantine restrictions caused the low submissions. Findings revealed that there was a significant difference in the output submissions before and after the implementation of the Google Classroom.
\end{abstract}

Keywords: output, submission, pandemic, google classroom, online means

\section{RESUMEN}

Esta investigación de acción se llevó a cabo para determinar si hay una mejora en los resultados presentados por los alumnos de $5^{\circ}$ y $6^{\circ}$ grado a quienes se les dieron módulos para realizar. Los encuestados del estudio fueron los maestros de los niveles superiores que recopilaron las presentaciones de los módulos durante el año escolar 2020-2021. El investigador utilizó un diseño descriptivo para ver si había un cambio significativo en la retroalimentación de los maestros que recibieron los módulos antes y después de la implementación de la intervención. Los datos recopilados fueron analizados y tratados estadísticamente mediante estadística descriptiva. Se identificaron factores que contribuyeron a los bajos niveles de presentaciones. La pandemia y las restricciones de la cuarentena provocaron las bajas presentaciones. Los hallazgos revelaron que hubo una diferencia significativa en los envíos de resultados antes y después de la implementación de Google Classroom.

Palabras clave: salida, envío, pandemia, google aula, medios en línea

\section{RESUMO}

Esta pesquisa-ação foi realizada para determinar se há uma melhora nos resultados apresentados pelos alunos do $5^{\circ}$ e $6^{\circ}$ ano que receberam módulos para realizar. Os entrevistados do estudo foram os professores dos níveis acima que coletaram as submissões do módulo durante o ano letivo 2020-2021. Um desenho descritivo foi utilizado pela pesquisadora para verificar se houve uma mudança significativa no feedback dos professores que receberam os módulos antes e depois da implementação da intervenção. Os dados coletados foram analisados e tratados estatisticamente por meio de estatística descritiva. Foram identificados fatores que contribuíram para os baixos níveis de submissões. A pandemia e as restrições de quarentena causaram as baixas submissões. Os resultados revelaram que houve uma diferença significativa nos envios de saída antes e depois da implementação do Google Classroom.

Palavras-chave: saída, submissão, pandemia, google sala de aula, meios online

\section{INTRODUCTION}

The Covid19 pandemic has lingered for more than a year and has affected many aspects of the communal world. Moreover, it detached everyone physical and at some point, socially. Especially in the implementation of the quarantine in varying degrees, everyone has gone himself masked up, anonymous, and on his own. Minimizing meetings involving physical contact is a priori 
in everything to help reduce the spread of the virus (Irawan, et al, 2020). Worse, these measures included social distancing and the temporary physical closure of educational institutions or a shift of instructional means (Armstrong-Menstrah, et al, 2020). The Philippines is of no exception. While the country's president has announced a dry-run for face-to-face classes, it was again withdrawn due to a resurgence in the number of the infected (Magsambol, 2020).

While schools remain off-limits for physical classes, the agency implemented various instructional means. During the first quarter of the school year under the pandemic, Fourth Estate Elementary School BF Homes implemented the modular system. The modular delivery gives the qualities that shall make the learners independent, and progressing on his own terms (Nardo, 2017). Parents had to visit the school on a schedule, considering the IATF safety protocols, to pick the modules for their children. While there are studies regarding the effectiveness of IATF in terms of reducing the number of the infected (Espia, et al, 2021), the school followed its protocol.

MAPEH teachers use varying instructional materials and modes of assessments, pupils are expected to perform. Considering that it is composed of Music, Art, PE, and Health as learning components, it is obvious that grades would depend heavily on performances. There are teachers who have identified other Classroom Assessment Techniques (Tabuena, 2017). However, as much as the teacher performs, unmotivated pupils do not meet the same level of enthusiasm. Considering that the study was conducted in a public school, it is composed of those coming from a low socioeconomic status. Teddlie and Stringfield believe that those coming from this level perform lower than those who are not (2017). And as mentioned earlier, this level of concern, intent to perform, the desire to get better grades, the drive to be schooled, go lower and unfortunately worsen as section levels go lower.

With these things in mind, the researcher intends to enhance the quality of the output in MAPEH produced by these pupils through the Google Classroom.

The researcher would like to find answers to the following questions:

1. What are the factors contributing to the poor outputs in MAPEH of these Grade 6 pupils from sections Edison and Bell?

2. What are the rates given by teachers for the outputs of the respondents done before and after their involvement in the Google Classroom?

3. Is there a significant difference in the rates given for outputs of respondents before and after their participation in the Google Classroom?

Hypothesis

Ho: There is a significant difference in the rates given for outputs of respondents before and after their participation in the Google Classroom.

\section{Innovation, Intervention and Strategy}

As a MAPEH teacher in Grade 6, the researcher plans activities, outputs, and projects for students that would enhance and show their understanding, comprehension, skills, and talents in the different components of the subject. One way to gauge if the student understood the lesson taught is through these different outputs and activities they are tasked to do after the discussion. Often these would integrate drawings and illustrations aside from actual performances and group presentations. The researcher observed that there are students who do not show much enthusiasm in coming up with good group presentations and actual performances in any of the four components of MAPEH. The intention to simply pass the minimum is obvious among these pupils. It was also observed that the submitted outputs were done in haste. May it be a musical performance, a dance, art output, essay in Health, or even a sports-related activity, these pupils do not show the intent to get a good grade. It is for this reason that the researcher came up with the idea of using the Google Classroom to be the means of instructional delivery and submissions. 
20 students involved in the study were those who consistently submitted poor and minimal outputs in the 1st and 2nd quarters. Invitations were sent to their parents about the intent of the researcher to move them into joining the Google Classroom. According to Hussaini and Libata, the Google Classroom is effective in improving Students' participation (2020). While there are many who believe that Google Classroom is an efficient and effective means of delivering instructions provided one knows how to (Sajid, 2020), and that it improves the students' average achievements (Syakur, 2020), there are studies stating that it lacks significant impact on teaching methodologies when analyzed before the teacher's perspective (Azhar \& Iqbal, 2018).

\section{THEORETICAL FOUNDATION}

This study was founded on the theory of Connectivism and Collaborative Learning. Connectivism is the system of integrating technology into academic instructions (Gallagher, et al. 2015). The core of connectivism is not merely connecting to the internet but the connecting of the thousands of networks capable of giving synchronous and asynchronous learning instructions (Kropf, 2013). Google Classroom is one of the trending Learning Management System (LMS) that takes connectivism as its ground. Collaborative Learning is a system that involves students to work together in solving a problem, completing a task, performing or crafting a project (Yeboah \& Yuan, 2017). Kelly believes that collaborative learning induces higher-level thinking and longer preservation of information (2017).

In the Google Classroom, both Connectivism and Collaborative Learning are considered. More than using the technological platform vis-a-vis Connectivism, the LMS also made popular the synchronous and asynchronous instructions. Accordingly, students' lives are tied to the Google Workspace (Smith \& Mader, 2018). This means that students enrolled in the Google Classroom are using technological tools such as Google Docs, Google Forms, Google Sheets, Google Slides and even other third-party apps to the Google Chrome. It also promoted collaborative learning as the LMS allows the connection of the students themselves within. Mcglynn and Kelly write that as teachers using Google Classroom, they encourage their students to build relationships and use each other as resources (2019). The respondents themselves had to work together in some of the tasks assigned.

\section{METHODOLOGICAL PROCEDURES}

This chapter presents the design, sampling method, instrument, procedures, and data analysis of the study.

\subsection{Research Design}

Descriptive research design was utilized to determine if involving the sample learners in the Google Classroom would enhance the outputs in MAPEH of Grade 5 and 6 pupils. The gathered data of the researcher were analyzed using descriptive statistics.

\subsection{Respondents and Sampling}

Respondents for the research were 20 pupils from the two Grade 6 sections, VI-Edison and VI-Bell, that are handled by the researcher. 10 pupils from VI-Edison and 10 pupils from VI-Bell These pupils were chosen from the list of students who consistently submitted poor outputs during the first and second quarters of the school year 2019-2020.

\subsection{Research Instrument}


The researcher prepared a simple survey questionnaire to determine the factors for the poor outputs of these pupils. This was translated to Filipino for the ease of the pupils. Translating research instruments to make it efficient and effective has been a practice (Tsang, 2017). The instrument was a researcher-made survey questionnaire which stated five possible answers from the question. The researcher followed the Guttman scale in determining the level of the respondents' involvement in the given stances in the questionnaire. The Guttman Scale measures how strong or how weak is the respondent's level towards the stance stated in the questionnaire (Jovancic, 2020). Accodingly, a reliable and valid researcher-made questionnaire should go through a development and validation process (Ngah, et al., 2022). This was checked and validated by the Assistant to the Principal and the Master Teachers of Fourth Estate Elementary School BF Homes.

\subsection{Data Gathering Procedure}

The researcher asked permission from the School Head before the conduct of the study. As soon he received the approval, he distributed the questionnaires to the respondents through Google Forms. The researcher also explained to the learners how they would answer the questionnaires on a synchronous meeting via Google Meet. The responses were automatically registered in the Google Forms/Sheet.

\subsection{Data Analysis}

To get the factors and their levels contributing to the poor outputs in MAPEH, the researcher computed the mean. The given rates of the respondents' performances before and while in the Google Classroom were compared using the t-test.

\section{RESULTS AND DISCUSSION}

The data gathered for the research were tallied and analyzed. With 20 pupils as respondents, the data gathered below show the frequency and percentage results of the survey regarding factors contributing to the poor outputs in MAPEH of Grade 6 students.

Table 1 Factors for Poor Outputs in MAPEH of Grade 6

\begin{tabular}{|c|c|c|c|}
\hline Questions & WM & VI & Rank \\
\hline Q1. Does not know what to do & 2.7 & A & 4.5 \\
\hline Q2. Does not want to perform in front & 3.5 & SA & 1 \\
\hline Q3. Does not find the output needed. & 3.45 & SA & 2 \\
\hline Q4. Does not understand instructions & 2.7 & A & 4.5 \\
\hline Q5. No reason at all & 3.0 & A & 3 \\
\hline Composite Mean & $\mathbf{3 . 0 7}$ & A & \\
\hline
\end{tabular}




\section{Legend:}

Option Range Verbal Interpretation

3.25 - 4.00 Strongly Agree

$2.50-3.24$ Agree

$1.75-2.49$ Disagree

1.00 - 1.74 Strongly Disagree

Based on the weighted mean, data shows that not wanting to perform in front and not finding the output needed rank as the top 2 respondents' choices. It is believed by the researcher that these are the main factors for giving minimal efforts in outputs.

Factors such as not knowing what to do and not understanding instructions are considered factors to poor performances. According to the responses, there were also those who do not perform for no reason at all.

Table 2 Average of Rates Given by Teachers for Output in MAPEH Before Joining and While in the Google Classroom

\begin{tabular}{|c|c|c|}
\hline Respondent & Before Joining & In Google Classroom \\
\hline R1 & 77 & 84 \\
\hline R2 & 76 & 85 \\
\hline R3 & 79 & 90 \\
\hline R4 & 76 & 84 \\
\hline R5 & 75 & 82 \\
\hline R6 & 70 & 81 \\
\hline R7 & 78 & 85 \\
\hline R8 & 77 & 87 \\
\hline R9 & 79 & 84 \\
\hline R10 & 70 & 81 \\
\hline
\end{tabular}

\begin{tabular}{|l|l|l|}
\hline R11 & 78 & 85 \\
\hline R12 & 75 & 84 \\
\hline R13 & 75 & 83 \\
\hline R14 & 79 & 82 \\
\hline R15 & 70 & 83 \\
\hline R16 & 77 & 88 \\
\hline R17 & 79 & 85 \\
\hline R18 & 79 & 87 \\
\hline R19 & 70 & 82 \\
\hline R20 & 78 & 85 \\
\hline MEAN & 75.85 & 85 \\
\hline
\end{tabular}

Table 2 shows that the teachers gave higher ratings to the outputs in MAPEH submitted by the learners when the class works were delivered and submitted in the Google Classroom. Based on the rates given, it could be observed that there was an improvement in the output submitted by learners after the learners when they participated in the Google Classroom. 
Table 3 The Result of the Computed t-test Between the Outputs in MAPEH Before Joining and While in the Google Classroom

\begin{tabular}{|c|c|c|c|c|c|c|}
\hline Test & N & Mean & $\begin{array}{c}\text { Difference } \\
\text { Between } \\
\text { Means }\end{array}$ & t-value & V.I. & Decision \\
\hline Before Joining & 20 & 75.85 & 8.5 & 11.5 & Significant & Keep \\
\cline { 1 - 2 } In Google Classroom & 20 & 84.35 & & & \\
\hline
\end{tabular}

Table 3 shows the results of the test of significant difference between the outputs of Grade 5 and 6 students after they joined the Google Classroom. It shows that the outputs after joining the are given a higher rating as indicated by the mean difference of 8.5 . The difference between the rates given for the outputs before and after the involvement in the Google Classroom showed a computed t-value of 11.5. It also shows that there is a significant difference in the rates given by teachers for outputs before involving the pupils in digital class and the rates given after letting them join. Higher ratings were given to the latter.

Therefore, the hypothesis that there is a significant difference in the rates given for outputs of respondents before and after the Google Classroom is maintained.

\section{CONCLUSION}

Based on the results of this research, the following conclusions were drawn:

1.The factors that contribute to the poor outputs of the respondents in MAPEH are: (a) students do not know what to do; (b) they do not want to perform in front; (c) they do not find the output necessary; (d) they do not understand the instructions; (e) and no reason at all.

2. Teachers gave higher ratings to outputs submitted after involving them in the Google Classroom. 3. There is a significant difference in the rates given by teachers for outputs of respondents between before joining and while in the Google Classroom.

\section{b. Implications}

The study proved what experts have been saying all along; using technological tools help the pupils improve their performance. The assumed unintentional gearing for optimal performance was fixed by making the learners motivated through being a part of the Google Classroom. This was attested in the output submission of the 20 pupils in the digital class. Teachers may use this instance to explore other LMS which is appropriate to their learners. MAPEH department can produce programs for teachers, ICT-tailored curricula, and ICT-based productions to strenghten the impact of the Google Classroom and other similar systems to the performance of the learners. Future researchers can explore other LMS and how it can help the MAPEH teachers in delivering instructions. They can also make a comparative study between the other LMS and the Google Classroom. Lastly, it is important for the teacher to consider the individual differences of students. There are pupils who seem to be uninterested but with a few tricks such as using the Google Classroom, they started performing better.

\section{c. Limitations}


The researcher limited the study to the twenty (20) pupils from Grade VI-Edison and VI-Bell whose scores in the modular instructions were low. The LMS used in the conduct of the study is with the use of Google Classroom and it does not represent the external links that the researcher has included in his activities.

\section{REFERENCES}

Armstrong-Menstrah, Elizabeth, Ramsey-White, Kim, Yaney, Barbara and Self-Brown, Shannon (2020), COVID-19 and Distance Learning: Effects on Georgia State University School of Public Health Students, retrieved from https://www.frontiersin.org/articles/10.3389/fpubh.2020.576227/full

Azhar, Kaukab Abid \& Iqbal, Nayab (2018), Effectiveness of Google Classroom: Teachers’ Perceptions, https://www.academia.edu/37341927/EFFECTIVENESS_OF_GOOGLE_CLASSROOM_TEACHERS_PERC EPTIONS_Kaukab_ABID_AZHAR.

Espia, J. C., Gera, W., \& Hall, R. A. (2021). Local Adaptations to Central Government Shortcomings: COVID-19 Responses in the Cities of Iloilo and Cebu, Philippines. Contemporary Southeast Asia, 43(1), 53-62. https://www.jstor.org/stable/27035524

Gallagher, T.L., Fisher, D., Lapp, D., Rowsell, J., Simpson, A., Scott, R.M., Walsh, M., Ciampa, K. \& Saudelli, M.G. (2015). International Perspectives on Literacy Learning with iPads. The Journal of Education, 195(3), 15-25. http://www.jstor.org/stable/44510414

Hussaini, Iliyasu \& Libata, Ibrahim. (2020). Effectiveness of Google Classroom as a Digital Tool in Teaching and Learning: Students' Perceptions. 4. 51-54.

Irawan, Andi, Dwisona, Dwisona, Lestari, Mardi (2020), Psychological Impacts of Students on Online Learning During the Pandemic COVID-19. retrieved from http://ejournal.radenintan.ac.id/ index.php/konseli/article/view/6389

Jovancic, Nemanja (2020), What is the Guttman Scale and How to Use it in Your Surveys, https://www.leadquizzes.com/blog/guttman-scale/

Kropf, Dorothy C. (2013). Connectivism: 21st Century's New Learning Theory. European Journal of Open, Distance and E-Learning, v16 n2 p13-24 2013

Kelly, Grace (2017). Two (or more heads) Are Better Than One. https://consiliumeducation.com/itm/2017/01/04/twoor-more-heads-are-better-than-one/

Mcglynn, K., \& Kelly, J. (2019). Using technology to sensitively and sensibly meet students' needs in the science classroom. Science Scope, 43(4), 22-27. https://www.jstor.org/stable/26899096

Magsambol, Bonz (2020), Why PH schools remain closed a year into the pandemic, retrieved from https://www.rappler.com/newsbreak/in-depth/why-philippine-schools-remain-closed-year-into-pandemic-2021

Nardo, M. T. B. (2017). Modular Instruction Enhances Learner Autonomy. American Journal of Educational Research, 5(10), 1024-1034.

Ngah, H., Mohd Hairon, S., Hamzah, N. A., Noordin, S., \& Shafei, M. N. (2022). Development and Validation of Knowledge, Attitude, and Practice Questionnaire: Toward Safe Working in Confined Spaces. International Journal of Environmental Research and Public Health, 19(3), 1242. MDPI AG. Retrieved from http://dx.doi.org/10.3390/ijerph19031242

Sajid, Ayesha, (2020). Using Google Classroom Effectively: For Teachers and Students. https://appuals.com/googleclassroom-effectively/

Smith, B., \& Mader, J. (2018). SCIENCE 2.0: Organizing a Bit of the Google Ecosystem. The Science Teacher, 85(3), 20-21. http://www.jstor.org/stable/44843688

Syakur, Abd, Sugirin \& Widiarni (2020). The Effectiveness of English Learning Media through Google Classroom in Higher Education. http://biarjournal.com/index.php/biolae/article/view/218/251

Tsang, S., Royse, C. F., \& Terkawi, A. S. (2017). Guidelines for developing, translating, and validating a questionnaire in perioperative and pain medicine. Saudi journal of anaesthesia, 11(Suppl 1), S80-S89. https://doi.org/10.4103/sja.SJA_203_17

Tabuena, Almighty. (2021). A Pre-Experimental Research on the Implementation of Selected Classroom Assessment Techniques for Music, Arts, Physical Education, and Health. 2. 99-107. 10.11594/ijmaber.02.02.03.

Teddlie, C., \& Stringfield, S. C. (2017). A Differential Analysis of Effectiveness in Middle and Low Socioeconomic Status Schools. The Journal of Classroom Interaction, 52(1), 15-24. http://www.jstor.org/stable/45372836 